\title{
THE BEHAVIORAL, SOCIOECONOMIC, AND ENVIRONMENTAL FACTORS ASSOCIATED WITH LEPROSY IN KEDIRI, EAST JAVA: A PATH ANALYSIS MODEL
}

\author{
Anindita Hasniati Rahmah'), Ruben Dharmawan'), \\ Setyo Sri Rahardjoº \\ 1) Masters Program in Public Health, Universitas Sebelas Maret \\ 2) Faculty of Medicine, Universitas Sebelas Maret
}

\begin{abstract}
Background: Leprosy is a leading cause of preventable disability in many low and middle income countries, including Indonesia. It thereby poses a major public health challenge for the country. Leprosy can be so progressive that damages skin, nerve, extremity, and eye organs of the affected patients. Cumulative incidence of leprosy amounted to 200,000 cases worldwide, with the highest incidences occuring in India, Brazil, and Indonesia. This study aimed to examine thebehavioral, social economic, and environmental determinants of leprosy in Kediri, East Java, using a path analysis model.

Subjects and Method: This was a case control study conducted at the Leprosy Hospital, Kediri, East Java, from November to December 2017. A total sample of 150 study subjects consisting of 75 leprosy patients and 75 non-diseased subjects were selected for this study by fixed disease sampling. The dependent variable was leprosy. The independent variables were personal hygiene, education, employment status, family income, dwelling density, humidity, and migration. Data on leprosy diagnosis was taken from medical record. The other data were collected by questionnaire. The data were analyzed by path analysis.

Results: The risk of leprosy increased with poor personal hygiene $(b=-1.20 ; 95 \%$ $\mathrm{CI}=-1.92$ to $-0.49 ; \mathrm{p}=0.001)$, high humidity $(\mathrm{b}=0.73 ; 95 \% \mathrm{CI}=0.33$ to $1.43 ; \mathrm{p}=$ $0.040)$, and migration $(b=0.94 ; 95 \% \mathrm{CI}=0.14$ to $1.74 ; \mathrm{p}=0.022)$. The risk of leprosy was indirectly affected by family income, dwelling density, education, and employment status.

Conclusion: Poor personal hygiene, high humidity, and migration, directly affect the risk of leprosy. Education, employment status, family income, and dwelling density indirectly affect the risk of leprosy.
\end{abstract}

Keywords: leprosy, social economic, environmental, personal hygiene

\section{Correspondence:}

Anindita Hasniati Rahmah. Masters Program in Public Health, Universitas Sebelas Maret, Jl. Ir. Sutami 36 A, Surakarta 57126, Central Java.

Email: aninditarahma22@gmail.com. 